\title{
Die eulogie in 1 Petrus 1:3-12
}

\author{
J.H. Barkhuizen \\ Departement Antieke Tale \\ Universiteit van Pretoria \\ PRETORIA \\ E-pos: barkhuiz@libarts.up.ac.za
}

\begin{abstract}
The eulogy in 1 Peter 1:3-12

The eulogy in 1 Peter 1:3-12 shares a common form with those found in Luke 1:68-79, Ephesians 1:3-14 and the shortened version in 2 Corinthians 1:3 f.f. As in the case of Ephesians 1:3-14, the eulogy in 1 Peter plays an important introductory part: it sets the argument of the author in motion and contains themes and motifs that figure prominently in the remainder of the letter. In this article the focus is a possible strophic division of the eulogy, followed by a discussion of its formal characteristics, and its theological perspective. The style of the eulogy sets it clearly apart from that of the rest of the letter, and several rhetorical features as well as some grammatical problems are discussed. The main thrust of its theological perspective is the new birth of the believers, initiated through the resurrection of Jesus Christ. This new birth entails a life infused with a living hope focused on their future inheritance and salvation, preserved for them by the power of God, and which will be finally realised at the revelation of Christ at the end of times. This hope, and the love and faith of the readers, will sustain them amidst their present hardships and sufferings. The eulogy thus forms the basis for the auhtor's exhortations, expressed from 1.13 f.f., towards a life of faithful endurance.
\end{abstract}

\section{Doelstelling}

In sy navorsing oor 1 Petrus wys Schutter (1989:32-33) op die feit dat verskeie nie-Bybelse formele bronne in 1 Petrus teruggevind kan word, onder andere geloofstellings, himniese fragmente, doksologie en eulogie (kyk ook Richard, 1986:127-129). In hierdie artikel is dit juis die eulogie wat in die kollig sal kom. 


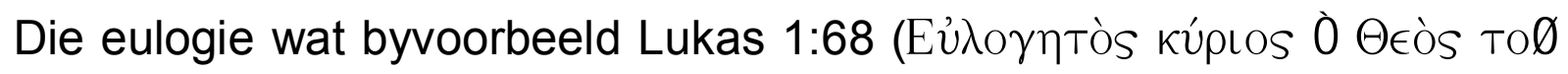

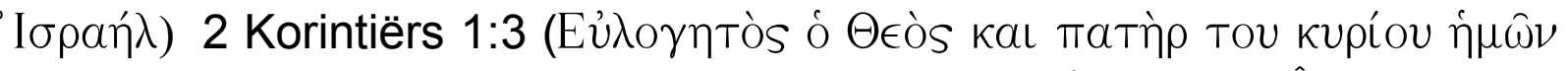

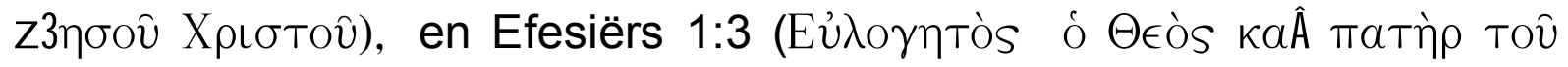

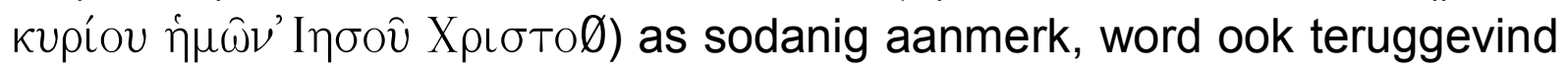
in 1 Petrus 1.3, terwyl die doksologiese refrein wat die himne in Efesiërs

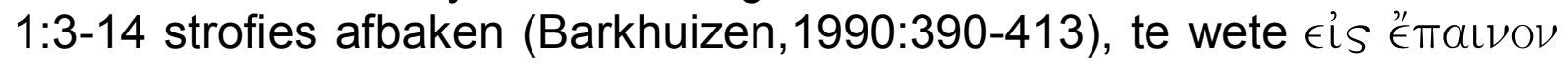

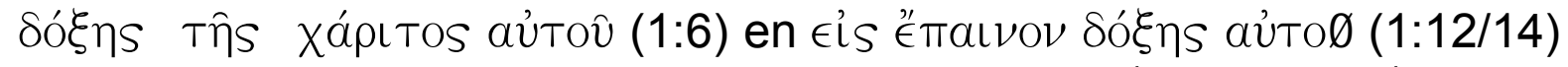

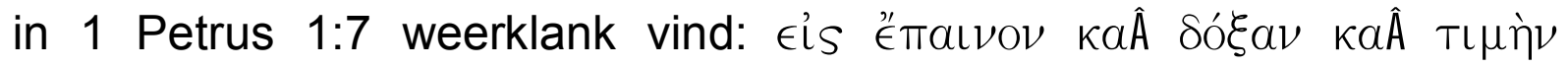
(Thúren,1995:96). Daarby onderskei die opeenhoping van adjektiewe, partisipia, apposisies, en ondergeskikte sinne (Lohse, 1986:47) dit duidelik van die styl in die res van die brief (uitgesonderd 2:22-24 en 3:18-22, wat poëtiese trekke vertoon - vgl. Arichea \& Nida, 1980:81).

Reeds uit die prominente posisie wat die bogenoemde eulogieë in die onderskeie tekste (evangelie- en briefgenre) inneem, dit wil sê reg aan die begin van die teks, wil dit voorkom asof hulle in dié teks die funksie van exordium of prooemium beklee. Indien dit wel so sou blyk, antisipeer hulle temas of motiewe wat verder in die betrokke teks uitgewerk word. Die doel van hierdie artikel is om deur 'n analise van die eulogie in 1 Petrus 1.3 e.v. die exordium-aard daarvan tot uitdrukking te bring. Om dit te kan verwesentlik is die interpretasie daarop gerig om antwoorde te gee op die volgende vrae:

- Wat is die presiese afbakening van die eulogie? (par. 2.1)

- Watter formele elemente kom hierin na vore; en wat is hulle funksie ten opsigte van die moontlike strofiese opbou van die eulogie? (par. 2.2-4)

- Wat is die teologiese perspektief van die eulogie? (par. 3)

- Watter funksie het die eulogie in die breëre opset van die brief? (par. 4)

\section{Afbakening en strofiese opbou van die eulogie}

As breë beginsel in die proses van afbakening en strofiese opbou is eerstens uitgegaan van die metode van diskoersanalise soos dit in die geval van 1 Petrus 1:3-13 reeds deur Du Toit (1974) toegepas is. Hierby moet egter in gedagte gehou word dat ons hier met 'n bepaalde diskoers te doen het, te wete 'n eulogie of loflied, wat bepaalde kenmerke weerspieël wat kan dien om die afbakening en opbou vas te stel. Terselfdertyd moet die oog ook gehou word op poëtiese en retoriese konvensies wat deel uitmaak van antieke tekste in die algemeen, en himniese tekste in besonder. 


\subsection{Afbakening}

Die presiese omvang van die eulogie word verskillend afgebaken: dit wissel van 'n eenheid wat bestaan uit verse 3-4/5 (Deichgräber, 1976: 77), 3-7 (Sanders, 1962:357), 3-12 (Windisch, 1951:52; Coutts, 1956: 115-127; Chevalier, 1972:134; Thurén, 1995:90-105; Achtemeier, 1996: 90), en 3-13 (Du Toit, 1974:65/70).

Gewoonlik bevat 'n eulogie twee basiese elemente: die oproep of stelling dat God geprys en gedank (moet) word (Kroll, 1968:3-17; White, 1972; 1984:1730-1756; Coutts, 1956:115-127), gevolg deur die redes daarvoor. As sodanig is dit ' $n$ bekende Ou-Testamentiese en Joodse formule: in die Ou Testament vind ons dit terug in onder andere Genesis 9:26, Psalms 66:20; 72:18; 106:48; en in Joodse geskrifte in byvoorbeeld 2 Makkabeërs 15:34.

Bloot grammatikaal gesien, vorm verse 3-12 'n hegte eenheid (in die Grieks is dit één sin), en dit geld as 'n sterk argument om dit as die volledige eulogie te aanvaar:

- 3-5 bevat die spesifieke lofpryse met die redes daarvoor;

- 6-12 vorm dan sowel inhoudelik as grammatikaal (Du Toit 1974:64) 'n uitbreiding op die lofprysing van God, net soos dit ook die geval is in die Magnificat en Benedictus en die eulogie in Efesiërs 1.3-14.

\subsection{Strofiese opbou}

\subsubsection{Kolon-struktuur}

As verse 3-12 in kola verdeel word, 1 kan 6 kola (met kommata) teruggevind word, wat as basis kan dien om deur middel van verdere beginsels tot 'n moontlike strofe-indeling te kom:

1. God, die Vader van ons Here Jesus Christus moet geprys word!

- In sy groot ontferming het Hy ons die nuwe lewe geskenk

* deur die opstanding van Jesus Christus uit die dood

* met die oog op 'n lewende hoop

* en 'n onverganklike, onbesmette en onverwelklike erfenis

wat in die hemel ook vir julle bewaar word;

en omdat julle glo, word julle ook deur die krag van

God bewaar vir die saligheid

wat reeds gereed is om aan die einde van die tyd geopenbaar te word.

1 Ter wille van ruimte word die voorafgaande ontledings in kola en kommata weggelaat. 
2. Hierin sal julle julle verheug ${ }^{2}$

- selfs al is dit nodig dat julle 'n kort tydjie bedroef gemaak (sal) word deur allerhande beproewinge

* sodat die egtheid van julle geloof getoets kan word;

julle geloof is kosbaarder as goud wat vergaan,

en wat ook getoets word met vuur;

* en sodat (julle geloof) lof en heerlikheid en eer waardig mag wees

by die wederkoms van Jesus Christus.

3. Hom het julle lief, al het julle Hom nie gesien nie;

4. En julle sal met 'n onuitspreeklike en heerlike blydskap gevul wees,

- deur in Hom te glo al sien julle Hom nou nie,

- $\quad$ terwyl julle so die verlossing verkry,

* wat die einddoel van julle geloof is.

5. In verband met hierdie saligheid het die profete deeglik en noukeurig ondersoek ingestel;

- hulle het die genade verkondig wat vir julle bestem is!

- hulle het probeer naspeur wie en watter tyd die Gees van Christus in hulle bedoel het ,

* die Gees wat vooruit verkondig het

dat Christus moes ly

en daarna verheerlik word.

6. Aan hulle is openbaar -

- dat wat hulle geprofeteer het

* nie vir hulle self bedoel was nie,

* maar vir julle.

Dit is nou aan julle bekend gemaak

deur dié wat die evangelie aan julle verkondig het deur die Heilige Gees

wat van die hemel af gestuur is;

Dit is dinge waarin selfs engele begeer om insig te kry.

\subsubsection{Lof-element as struktureringselement}

Wanneer daar nou nader gekyk word na 'n moontlike strofiese opbou, kan die volgende in gedagte gehou word:

- Kolon 1 (verse 3-5) vorm 'n hegte eenheid omdat dit die lof-element in engere sin van die woord bevat met die direkte rede daarvoor as eerste hoofuitbreiding op die lof-element. 
- Die verdere indelings loop gewoonlik uiteen wanneer dit kom by kola 2-6 (verse 6-12). Het ons hier met drie of vier strofes te doen, en waar word elkeen afgebaken?

\subsubsection{Relatiewe voornaamwoorde as struktureringselement}

As ons verse 3-5 op grond van sy hegte lof-element as 'n eerste strofe neem, vorm vers 6 die begin van 'n volgende strofe, wat ingelei word deur ' $n$ relatiewe voornaamwoord met preposisie. Op grond hiervan sou dit moontlik wees om die voorkoms van die relatiewe voornaamwoorde wat in verse 8-12 voorkom, tot sy volledige konsekwensie deur te neem. Hiervolgens kan die gedeelte dan in vyf strofes ingedeel word:

- 1.3-5: strofe een (basiese lof-element);

- $1: 6: \epsilon \nu^{-}$sluit aan by die frase "in die laaste tyd" van vers $5=$ strofe twee;

- 1:8: Ö v sluit aan by vers 7 se "Jesus Christus" = strofe drie;

- 1:10: $\pi \in \rho-\Omega$ s sluit aan by vers 9 se "verlossing" = strofe vier;

- 1:12: o $\tilde{Q}$ sluit aan by vers 11 se "profete", vervat in die werkwoord

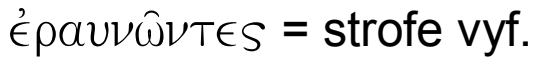

\subsubsection{Doksologie as struktureringselement}

Vers 7 word afgesluit met die refreinagtige doksologie wat ook uit die eulogie van Efesiërs 1.3-14 bekend is - met 'n driemalige voorkoms aldaar. Om hierdie rede sluit Sanders (1962:357) die eulogie dan ook af met vers 7, terwyl dit in bogenoemde afbakening bevestig dat verse 6-7 'n strofe vorm, wat weer eens die relatiewe voornaamwoord waarmee vers 8 begin, as moontlike afbakeningsbeginsel in hierdie geval ondersteun!

\subsubsection{Trinitariese konsep as struktureringselement?}

Waar verse 3-12 as volledige eulogie geld, wys Coutts (1956:115-127) daarenteen, in vergelyking met Efesiërs 1:3-14, op die bekende kenmerke wat dit deel met genoemde Efese-passasie: die eulogie-formule (1.3a), die doksologiese formule (1.7) en (volgens hom) die trinitariese struktuur. Alhoewel die teologiese perspektief van Efesiërs 1:3-14 wel 'n trinitariese perspektief bevat, soos ook hier in 1 Petrus 1.3-12, het Barkhuizen (1990:390-413) dit afgewys as enigste afbakeningsbeginsel en 'n nie-trinitariese strofe-bou vir Efesiërs 1:3-14 voorgestel. In hierdie verband waarsku Du Toit (1974:69) dan ook teen 'n blote gedagte- of inhoudelike konsep as struktureringsbeginsel: "And yet a Trinitarian divisioning, regardless of its beauty and theological importance, should 
not be regarded as a decisive principle for classification here." Alhoewel die Gees van Christus (= Heilige Gees) in verse 10-12 voorkom en hierdie verse op grond hiervan as één strofe ingedeel sou kon word, is die probleem met 'n trinitariese perspektief dat sowel God (die Vader) as Jesus Christus in die eerste strofe voorkom.

Opsommend sou dan gestel kan word dat ons hier met 'n tipiese eulogie te doen het (3-5), waaraan daar deur middel van 'n konstante gebruik van relatiewe voornaamwoorde en 'n doksologiese frase, vier eenhede (soos aangedui onder 2.2.3 hierbo), toegevoeg word as verdere uitbreiding op die lof-element van 3-5.

\subsubsection{Enkele ander strofiese strukture}

- Chevalier (1972:134) se indeling is dié van drie strofes: 3-5; 6-9; 10 12 , waardeur egter eerstens die afsluitende funksie van die doksologie van vers 7 aan effektiwiteit inboet, en tweedens die afsluitende

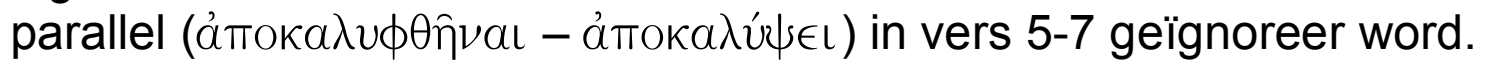

- Achtemeier (1996:90) verdeel dit in drie dele, waarvan die tweede en derde deel elk twee onderafdelings bevat wat deur middel van relatiewe sinne (!) ingelei word. Die groot skeidings val vir hom in 1:6 en $1: 10$. Sy indeling is dan: strofe $1=3-5$; strofe $2=6-9$ (a. 6-7; b. 89); strofe $3=10-12$ (a. 10-11; b. 12). Dit beteken dat hy in werklikheid ook 'n vyfdelige eenheid ondersteun.

- Thurén (1995:90-105) verdeel dit in vier strofes: 3-5; 6-7; 8-9; 10-12. Ook Du Toit (1974:70) groepeer 10-12 saam, en alhoewel hy ook uitkom by vyf strofes, is dit as gevolg van die feit dat hy vers 13 as 'n résumé vertolk. Die verskil kom by hierdie twee geleerdes in by verse 10-12, wat 'n mens as eenheid sou kon beskou, maar soos hierbo aangetoon, wil dit tog lyk of die voorkoms van die relatiewe voornaamwoorde tesame met die kolon-indeling hier eerder twee strofes meer aanvaarbaar maak.

\subsection{Bespreking van grammatikaal-formele aspekte}

Voordat daar by die teologiese perspektief gekom word, volg eers 'n bespreking van bepaalde formele aspekte wat vir die interpretasie van belang is.

- Die eulogie self (1:3) kan óf as imperatief (laat God geprys word) óf as stelling gelees word (God word geprys).

- Die formele aanmerk van die rede(s) vir die lof op God het ooreenkomste met dié van ander eulogieë. In Lukas 1:68 word dit aangemerk deur ŐTl, in 2 Korintiërs 1:3 en Efesiërs 1:3 deur die lid- 


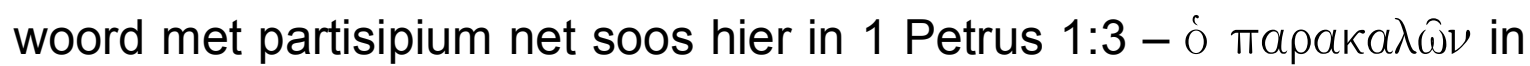
2 Korintiërs 1:3 en o $\epsilon \dot{u} \lambda o \gamma \eta \dot{\eta} \sigma a s$ in Efesiërs 1:3 in vergelyking met $\delta$

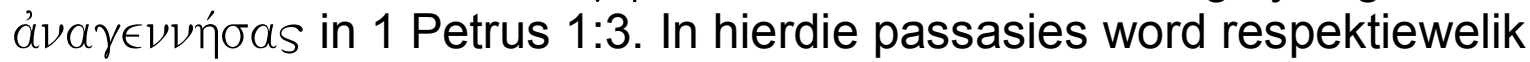

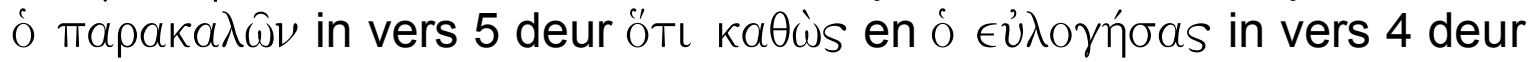

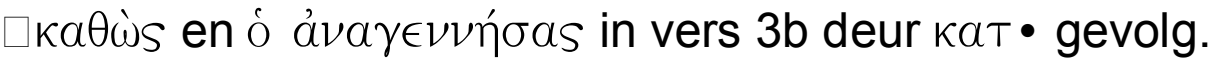

- Die nuwe lewe wat God hulle gegee het deur die opstanding van Jesus Christus, word formeel benadruk deur die assonerende herhaling van $\alpha \nu \alpha-$ in $\alpha \nu \alpha \gamma \in \nu \nu \eta \dot{\sigma} \sigma \alpha-\alpha \dot{\nu} \alpha \sigma \tau \alpha ́ \sigma \epsilon \omega s$.

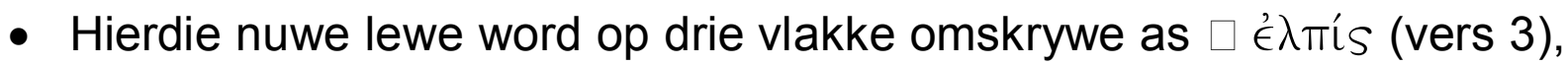

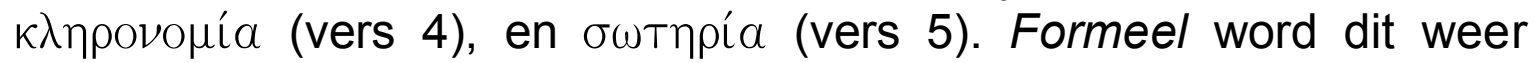
bevestig deur die drie maal herhaalde voorsetsel $\epsilon i s$ voor hierdie drie selfstandige naamwoorde.

- Die opeenstapeling van adjektiewe van die drie adjektiewe, met

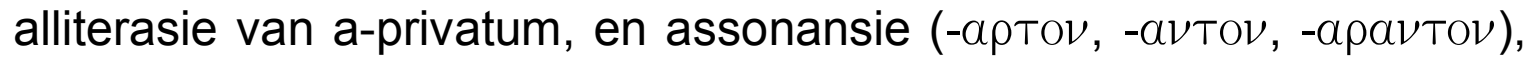
wat "erfenis" omskrywe (vers 4), beklemtoon die intrinsieke waarde van sowel die erfenis as die gelowiges se verlossing ten opsigte waarvan die lesers deur God beskerm word (waar $\epsilon^{\prime} \nu$ in die frase

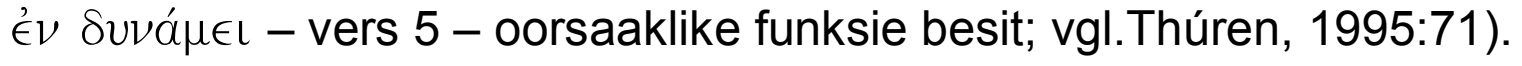

- Die tydsverwysende relatiewe uitdrukking (begin vers 6 ) het as antesedent "in die laaste tyd" (vers 5). Dit beteken dat die relatiewe

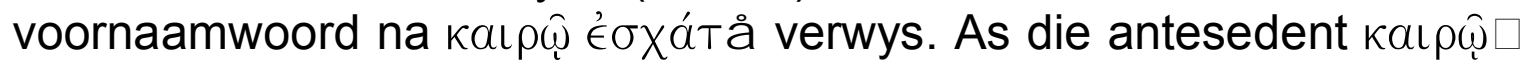
is, moet ' $n$ mens dan die teenwoordige (indikatiewe, nie imperatiewe) tyd van die werkwoord $\alpha \hat{\gamma} \alpha \lambda \lambda \iota \hat{\alpha} \sigma \theta \in$ toekomstig verstaan.

- Die werkwoord á $\gamma a \lambda \lambda_{\iota} \hat{\sigma} \sigma \theta \epsilon$ wat 'n eskatologiese ondertoon dra (Kendall, 1986:108; Martin, 1992:307), kan op drieërlei wyses verstaan word (Goppelt, 1978:98-99; Martin, 1992:307-312):

(1) as teenwoordige tyd met teenwoordige betekenis: "julle verheug julle";

(2) as teenwoordige tyd met toekomstige betekenis: "julle sal julle verheug";

(3) as teenwoordige tyd met imperatiewe krag: "verheug julle dan".

Die korrekte interpretasie van hierdie werkwoord is afhanklik van vier eksegetiese kwessies: (a) die modus daarvan; (b) die tydsverwysing van die partisipia afhanklik daarvan; (c) die ansedent en geslag van die relatiewe voornaamwoord ${ }^{-}$in vers 6 ; en (d) die gebruik van die teenwoordige indikatief met toekomstige betekenis.

(a) Die vorm $a \dot{\gamma} \alpha \lambda \lambda \iota \hat{\alpha} \sigma \theta \in$ kan óf indikatief óf imperatief wees. Die keuse vir imperatief (Du Toit, 1974:70) stuit egter teen die feit dat die skrywer in hierdie inleidende gedeelte eers die konteks stel waarin die brief gelees moet word, terwyl die aansporings 
eers in 1:13 begin (Kendall, 1986:104). Die indikatief lyk dus na 'n beter keuse.

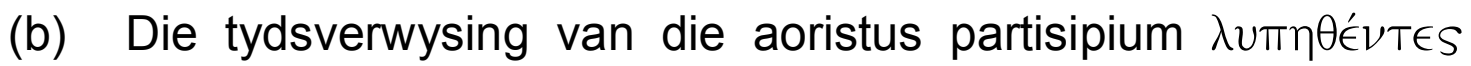
word nader bepaal deur äpTl "nou", sodat die teks laat blyk dat die lyding nou (in hierdie tyd van die lesers) plaasvind. Deur hierdie bywoord met die aoristus partisipium te gebruik, gaan die handeling van die partisipium die handeling van die hoofwerkwoord vooraf:

This adverbial adjunct $\ddot{\alpha} \rho \tau \iota$ creates an antithesis between the present events expressed by the participles and the future events expressed by the main antithesis between the present verb á $\gamma a \lambda \lambda \iota \hat{a} \sigma \theta \in$ (Martin, 1992: 309).

Louw en Nida (1988:67.38) se inskrywing bevestig hierdie standpunt deur na äp tı verwys as "a point in time simultaneous with the event of the discourse itself". Die enigste manier hoe hierdie teenswoordige lyding vóór die vreugde kan plaasvind, is as die vreugde as toekomstig veronderstel word. $\hat{a} \gamma a \lambda \lambda_{\iota} \hat{\alpha} \sigma \theta \in$ moet derhalwe gesien word as teenwoordige tyd met toekomstige betekenis.

(c) Die derde saak is die antesedent en geslag van die relatiewe voornaamwoord aan die begin van vers 6 . Alhoewel die argument dat dit onsydig is en na die hele voorafgaande drie verse verwys (3-5) ${ }^{3}$, grammatikaal moontlik is (vgl. Thurén, 1995:71; Du Toit, 1974:68; Achtemeier, 1996:100-101), is die eenvoudigste oplossing om dit te laat terugverwys na

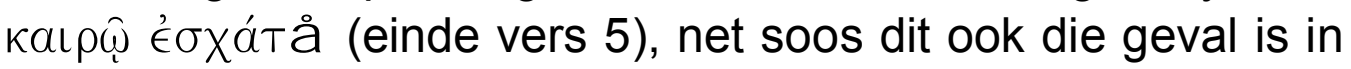
3:19, waar die relatiewe voornaamwoord terugverwys na die

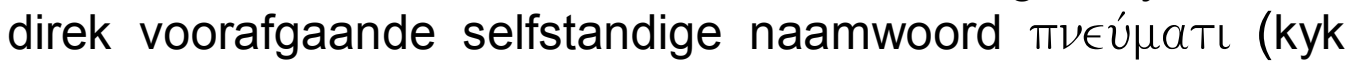
ook Fink, 1967:33-39).

(d) Wat die laaste aspek betref, wys grammatici daarop, en bevestig verskeie Nuwe-Testamentiese voorbeelde dit dat die teenwoordige tyd toekomstige betekenis kan besit. Smyth (1959:par.1879) sê byvoorbeeld: "The present is used instead of the future in statements of what is immediate, likely, certain ...", en Blass et al. (1979:par. 323) stel dit nog duideliker: "Bei bestimmten Versicherungen tritt ... gern das lebhaft vergegenwärtigende Präsens für das Futurum ein" (vgl. Rom. 2:16; 1 Kor. 15:32; Mark. 9:31). In die lig van wat hierbo verheug. 
gestel is, kan vers 6 soos volg vertaal word: “... op welke tyd sal julle julle verheug alhoewel dit nou nog nodig is dat julle vir 'n kort tydjie lyding ervaar deur menigvuldige beproewinge".

- Verse 8-9 geld as oksimoron, waardeur liefde vir en geloof in Christus gestel word teenoor die nie-sien van Christus. Die nie-sien van Christus en hulle verlossing kon gegeld het as 'n struikelblok en tot 'n ondermyning van hulle lewende hoop. Tog gebeur dit nie, waardeur die egtheid van hulle liefde en geloof deur die skrywer beklemtoon word.

- Formeel bied vers 8 met sy parallelle genegativeerde frases, waarin twee verskillende negatiefvorme (oủk, $\mu Z$ ) en twee verskillende werkwoordtye (verlede en teenwoordige tyd) voorkom, probleme:

- Die oúk, wat 'n historiese feit ontken, word nie gewoonlik met 'n deelwoord gekonstrueer nie, maar wanneer dit wel gebeur, gaan dit oor 'n algemeen geldende 4 saak: hulle het nie die historiese Jesus gesien nie. MZ, aan die ander kant, word hier in sy gewone funksie met 'n deelwoord gekonstrueer, en dui op hulle huidige niesien van Jesus.

- Andersins kan die tweede frase bloot die eerste versterk: "alhoewel nie, tog ... alhoewel nie, tog ..."

Achtemeier (1996:103) wil die probleem van hierdie parallelle frases

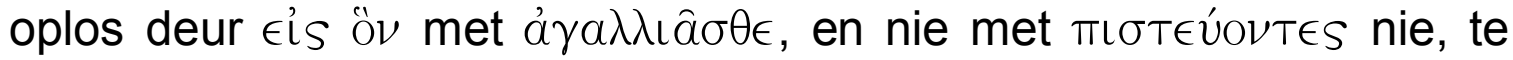
verbind: "in whom, although you do not now see but believe, you rejoice". Die probleem hiermee, soos hyself ook toegee, is dat die primêre parallel deur "liefhê" en "verheug" gevorm word, terwyl, soos in hierdie artikel betoog word, die blydskap toekomstige betekenis dra.

- Die gedagte van verlossing, waarmee strofe 3 (verse 8-9) afgesluit word, word in die vorm van 'n $\kappa \lambda \hat{\imath} \mu \alpha \xi$ hervat in die begin van strofe 4 (vers 10), waardeur die skrywer hierdie konsep van verlossing (in aansluiting by vers 4 - einde van die vers!) benadruk as troos vir sy lesers wat te midde van verontregting moet lewe.

- In vers 10 beklemtoon die retories en stilisties assonantiese paar en

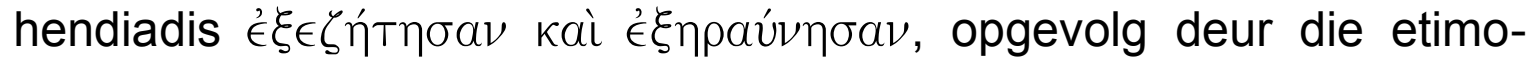

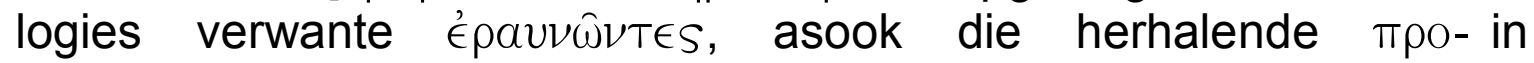

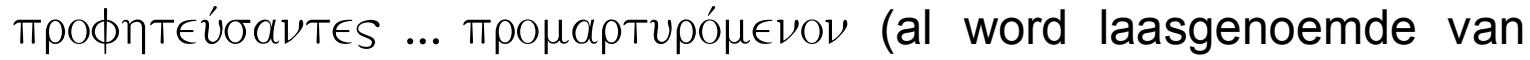

4 Hierdie funksie, wat nie baie voorkom nie, kan verder soos volg verduidelik word: 'n

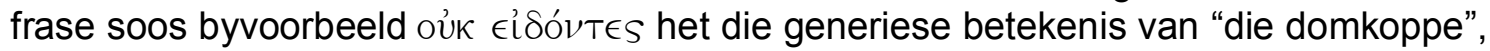

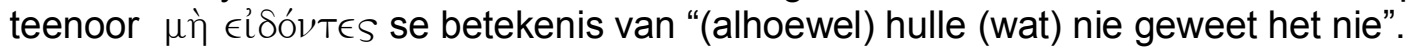


die Gees van Christus gesê) die volgehoue en deeglikheid van die profete se strewe om tot kennis te kom van hierdie verlossing.

- Grammatikaal lewer Tíva ク̈ Toîov (vers 11) probleme: albei kan verstaan word as vraende adjektiewe by kaıpòv ("watter of welke soort tyd"), of Tíva kan gesien word as vraende voornaamwoord wat selfstandig gebruik word: "wie en welke soort tyd". Albei gebruike kom in die Nuwe Testament voor, maar Achtemeier (1996:109) oordeel dat "inquiry into events and times is more frequent in apocalyptic Judaism than inquiry into person and times ..." Hierteenoor argumenteer Kilpatrick (1986:91-92), in aansluiting by Blass et al. (1979:298(2)) wat sê dat Tís gewoonlik 'n voornaamwoord is en moîos 'n adjektief, oortuigend $\mathbf{5}$ vir die verstaan van die frase as: "wie is die Messias en wanneer sal Hy kom?" Vir hierdie Messiaanse identiteit kan tekste soos Matteus 11:3, Markus 8:29 en Lukas 3:15 vergelyk word, en vir die tyd Handelinge 1:6.

- In vers 12 vervul sowel die relatiewe voornaamwoord (oîs) as die

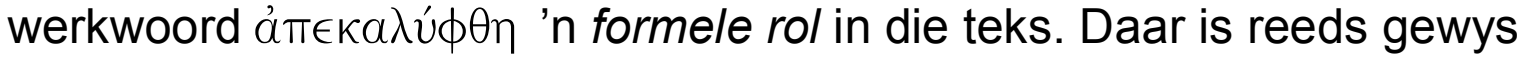
op die relatiewe voornaamwoord ois se afbakeningsfunksie, terwyl die driemalige voorkoms van die relatiewe voornaamwoord (oîs, û, $\in$ is û) volgens Achtemeier (1996:90) 'n manier kan wees om die afsluiting van die prooemium aan te dui.

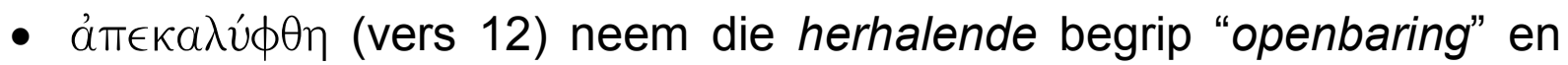
"openbaar" (op prominente posisies in die teks: verse 5/7) tot sy konklusie, en vorm daarmee saam 'n reeks van passiewe in hierdie slotstrofe: "is geopenbaar" (aan die profete), "is verkondig" (aan die lesers), en "is gestuur" (van die Heilige Gees gesê). Sulke passiewe is tipies van belydenisformulerings, soos byvoorbeeld in 1 Timoteus $3: 16 \mathrm{~b}$ gesien kan word, en waardeur die afbakening van die eulogie tot en met vers 12 onderstreep word.

- Ten slotte wil die herhaling van die woord "julle" in vers 12, die eerste keer in jukstaposisie met die "profete" (Éavtoîs ijîv), om groter kontras te verleen, die bevoorregte posisie van die lesers bo dié van profete én engele beklemtoon.

\section{Teologiese perspektief}

Die eulogie vorm deel van die exordium of prooemium 6 van die brief (1:1-12). As sodanig wil dit, soos elders by Paulus, as funderende

$5 \quad$ Kilpatrick (1986) verwys na verskeie gebruike in die Nuwe Testament om sy argument te staaf.

$6 \quad$ Vir hierdie twee terme kyk Quintilianus Inst. 4.1.5. Die inleidende twee verse (1.1-2) geld as die inscriptio. 
inleiding tot die hoofgedeelte van die brief dien, want die gedagte van 'n lewende hoop te midde van beproewinge en lyding figureer prominent in die eulogie. Kendall (1986:104) skryf in dié verband: "The author's introductory declarations concerning the nature of Christian existence serve as the foundation for the exhortations that compromise the bulk of the epistle (1:13-5:11)". Ten spyte van Goppelt (1982:161-178) en Neugebauer (1980:61-86) wat die lydingskarakter van die brief afskaal tot blote diskriminasie eerder as werklike vervolging, is die talle verwysings na "Iy"/"lyding" in verhouding met die brief te opvallend. Die brief is gerig tot Christene wat onder lydingsomstandighede verkeer. Dit is die skrywer se bedoeling om hulle te versterk en te troos te midde van hulle aanvegtinge (Lohse, 1986:42).

Soos reeds geblyk het uit die formele uiteensetting, beslaan die eulogie 'n uitgebreide motivering waarom God onder sodanige omstandighede geprys moet word, en die indeling (en die bespreking) van 1:3-12 in "strofes" help inderdaad om die komplekse gedagtegang van die eulogie te volg.

\subsection{Strofe 1 (verse 3-5):}

Soos aangedui in die inleidende paragrawe, gebruik die skrywer 'n bewoording wat ooreenstem met dié wat Paulus (en Lukas) gebruik, wat daarop dui dat dit as tradisionele formulering binne die kerklike liturgie bestaan het: "an early Christian doxological formula" (Achtemeier, 1996: 93). Die verwysing na God as "die God en Vader van ons Here Jesus Christus" is 'n nadere omskrywing van Lukas se "die Here, die God van Israel" (1:68), wat uit die Ou Testament stam - 1 Samuel 25:32; 1 Konings 1:48; Psalms 40:14; 71:18: Israel het God ook geken as "Vader", maar hier word die volle openbaring van God se Vaderverhouding met sy volk in Jesus Christus uitgelig. Hierdie besondere openbaring word versterk deur die verwysing na Jesus as kúpıos, die LXX-titel van God in die Ou Testament. Die uitdrukking "Jesus is Here" was 'n vroeg-Christelike belydenisformule (kyk Hand. 8:16; 19:5; Rom. 10:9; 1 Kor. 12:3; 2 Kor. 4:5; Fil. 2:11, en Ignatius (Ad. Eph. 7.2). Kelly (1969:47) meen dat dit aan Jesus toegeskryf is as verrese en opgevaarde Here.

Die motivering om God te prys is gebaseer op verskeie sake wat soos 'n bouwerk daargestel word: die een "rede"/"motivering" vloei oor in die ander en vergestalt sodoende die totale verhouding van God die Vader

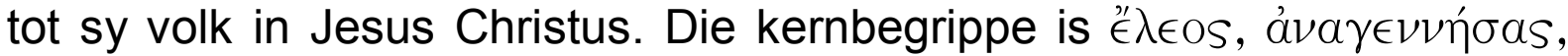

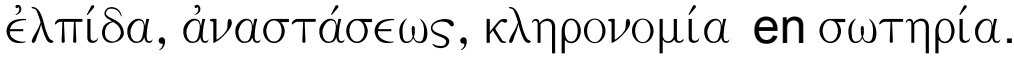


- Die basis van hierdie verhouding tussen God en sy volk/gemeente het sy oorsprong in sy medelye en barmhartigheid, soos Petrus dit in 2:10 omskrywe (kyk ook Tit. 3:5):

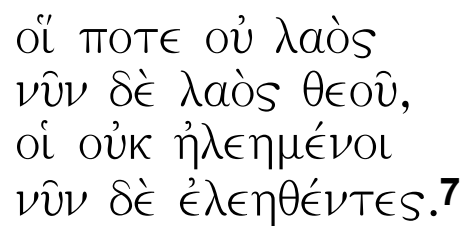

Die feit dat Petrus dit omskrywe as "groot", is waarskynlik 'n bewuste terugspieëling van Ou-Testamentiese taalgebruik, soos te vinde in Eksodus 34:6; Numeri 14:18; Psalm 86:5,15.

- God se barmhartigheid is daarop gemik om hulle wat in Hom glo nuut te skep, wat hier (en in 1:23 en 2:2) in 'n soortgelyke beeld uitgedruk word as Jesus se voorstelling daarvan in Johannes 3:3-8 teenoor Nikodemus, en ook verwoord is in Efesiërs 2:4 e.v., Titus 3:5b, 1 Johannes $2: 29 ; 3: 9 ; 4: 7 ; 5: 1$, en Jakobus $1: 18$. Sowel Hippolytus (Ref. 5.8.10;23) en Tertullianus (De bapt. 5.1) bevestig dat hierdie beeld ook in die Hellenistiese wêreld figureer: die volgelinge van Isis (kyk Apuleius, Met. 11.21), Mithras en Kubele (CIL VI,510) het bekend gestaan as renati (nuutgeborenes) op grond van hulle sakramentele inwyding. Dit beteken egter nie dat die gebruik van die beeld hier noodwendig onder Hellenistiese invloed staan nie, en dit is verder belangrik om daarop te wys dat alhoewel Christelik-literêre vorme ooreenkomste vertoon met nie-Bybelse vorme, die inhoud uit die Christelike milieu self stam (die geïnspireerde openbaring van God). Christene is dus mense wat in Christus "nuutgeskep" is en daarom nuwe mense is. Louw en Nida (1988:13.55) wys daarop dat "In its NT usage $\alpha \nu \alpha \gamma \in \nu \nu a ́ \omega$, of course, has nothing to do with birth as such, but refers to a radical change in personality ...". Dit word ook bevestig deur Achtemeier (1996:94) dat dit om meer as net hergeboorte gaan: dit is eerder "herverwekking" - 'n totaal nuwe oorsprong! Die skrywer se gebruik van hierdie beeldspraak - "spiritual rebirth" (Louw \& Nida,

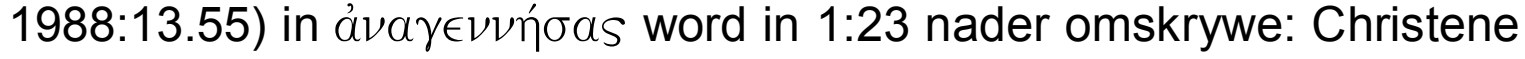
is mense wat nuutgebore is ( $\dot{\alpha} \nu \alpha \gamma \in \nu \nu \eta \mu \epsilon ́ \nu \mathrm{ol})$, nie uit verganklike saad nie, maar uit onverganklike saad: die lewende en ewige woord van God.

- In die beeld van die nuwe geboorte (wat voortvloei uit die gedagte van "nuutskep"), met God as "Vader", word die "moeder"-element vervang met die opstanding van Jesus Christus uit die dood. Marshall voor in die twee eulogieë in Lukas1:50/54 (Magnificat) en Lukas 1:72 (Benedictus). 
(1991:36) se stelling: "The metaphor is not pushed beyond the thought of the engendering of life, the action of the Father alone being envisaged with no thought being given to any metaphorical equivalent of a mother" is dus net gedeeltelik korrek: die moeder-element word wel onderdruk, maar dan tog vervang met die opstanding van Jesus Christus uit die dood $\mathbf{8}$. Die nuwe geboorte vind plaas deur Christus se opstanding. So verbind die 1983-Afrikaanse vertaling dit ook, en skrywe Kelly (1969:48): "Christ's resurrection is the ground and guarantee of our resurrection hope". Du Toit (1974:62-63) bevestig ook dieselfde gedagte: "our hope is alive ... because Jesus Christ has been resurrected from the dead"; so ook Kendall (1986:107): "This new existence is grounded in the resurrection of Jesus ...". Waar die gedagte van die kruis en die kruisdood die plaasvervangende en versoenende aspek van die verlossing is, is dit die klem op Jesus se opstanding uit die dood wat as die regenererende aspek van die nuwe lewe geld.

- Die doel ( $\epsilon$ is + akk.) van hierdie nuwe geboorte is eerstens die verkryging van 'n lewende hoop: $\epsilon i s ~ \epsilon ̇ \lambda \pi i ́ \delta a \zeta \omega \hat{\omega} \sigma \alpha \nu$. Die hoop word as "lewend"omskrywe waarskynlik omdat dit (a) in die gelowiges lewe (3:15), en (b) op die ware lewe gerig is, en derhalwe egte hoop is, en (c) daarom effektief en seker is (nie dood of oneffektief nie). Hoop is een van die sleutelwoorde in die brief en staan in noue verband met die toekoms van die Christene wat in 'n vyandige wêreld lewe, soos blyk uit 1:13, 21; 3:15: die hoop van die gelowiges transendeer hierdie vyandige wêreld en die fisiese dood, en vind sy verwerkliking in die nuwe wêreld van God wat by die openbaring van Christus $(1: 5,7,13)$ ten volle intree.

- Die tweede doelstelling van die nuwe lewe word uitgedruk deur die beeld van 'n erflating, wat waarskynlik deur die voorafgaande beeld van die wedergeboorte tot nuwe kinders geïnspireer kon gewees het (Kelly, 1969:50), terwyl die beeld natuurlik ook 'n ryke tradisie in die Ou Testament gehad het (Grosheide, 1954:142), waar dit verwys het na óf Kanaän (Deut. 15:4;19:10), óf God self (Ps. 16:5), óf die ewige lewe (Dan. 12:13; en Grosheide, 1954:143) . Verder word die gedagte van 'n eskatologiese erfenis reeds weerspieël in die Jesus-logia (Matt. 5:12a; 6:19-20; Luk. 12:33). Vir Paulus is Christene God se erfgename en hulle erfenis word soms geassosieer met ewige lewe (Tit. 3:7), heerlikheid saam met Christus (Rom. 8:17), onsterflikheid (1 Kor. 15:50), die koninkryk (Ef. 5:5), terwyl vir die skrywer van Hebreërs

8 Die noue band tussen "nuutskep" en "opstanding" word ook formeel bevestig deur die

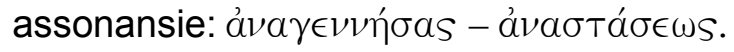


(1:14) dit heenwys na verlossing - dit is dus duidelik eskatologies in wese, soos bevestig deur die skrywer se beskrywing van hierdie erfenis as onverganklik (kyk ook 1:23; 3:4), onbevlek en onverwelklik (kyk ook 5:4). As sodanig karakteriseer hy die erfenis se ware aard as iets wat geheel en al anders is as die gewone menslike besittings. Grosheide (1954:143) praat van heilsgoedere (teenoor aardse goedere), en as sodanig transendeer dit hierdie vyandige, maar verbygaande en sterflike wêreld. Verder word die heilsgoedere bewaar soos 'n skat vir die gelowige in die hemele (die woonplek van God, en dus die sfeer van verlossing en geluksaligheid), sodat geen aardse katastrofes - lyding of vervolging of verganklikheid - in hierdie wêreld waarin die gelowiges nou lewe, die gelowiges van hulle ware bestemming kan berowe nie.

- Laasgenoemde gedagte word verder bevestig deur die slotvers van die eerste strofe. Nie net word die erfenis bewaar nie, maar ook die erfgename daarvan ${ }^{9}$, en dit deur die krag van God, en omdat hulle glo. Marshall (1991:38) skrywe in dié verband:

This ... shows that God's power does not work automatically, regardless of the attitude of the Christian. It is as Christians trust in God that they experience his power to protect them.

Hierdie feit hang saam met die hele etiek van die Nuwe Testament wat gebaseer is op die formule van indikatief-imperatief ("Wees heilig, want Ek is heilig" in 1:16): God bewaar die gelowige deur sy krag, maar die gelowige moet in hierdie krag van God glo. Die beeld wat hier deur die skrywer opgeroep word, is dié van "a position guarded

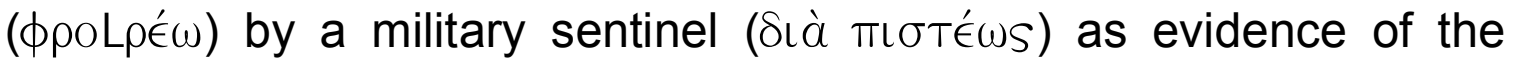

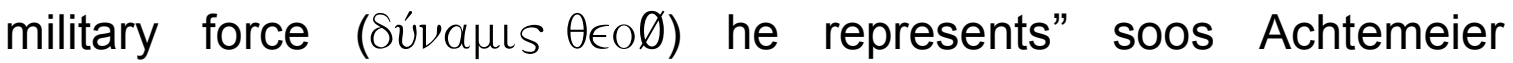
(1996:97) dit stel (ook Grosheide, 1954:144). Die geloof van die gelowiges is dan inderdaad die instrument waardeur die goddelike beskerming 'n realiteit word. Die uitdrukking "deur die geloof" kom $16 x$ in Paulus voor, maar elders in die Nuwe Testament net nog een maal in Handelinge, sodat ons hier dalk Pauliniese invloed kan vermoed (Seethaler, 1985:20).

- Die gelowiges se nuwe lewe en hulle bewaring deur God se krag omdat hulle in God glo, is derdens gerig op hulle verlossing wat aan die einde van die tyd verwerklik word. Verlossing is sowel die objek van die gelowiges se lewende hoop as die inhoud van hulle erfenis. Verlossing behels verder waarskynlik in die konteks van hierdie brief (teteremenen and phrouroumenous) in the Greek ..." 
onder andere die volgende: die gedagte van bevryding van die vyandige wêreld (lyding en vervolging), die dood, God se eskatologiese oordeel (Achtemeier, 1996:97), en ten slotte die betree van God se nuwe wêreld. Laasgenoemde tree eers ten volle in werking aan die einde van die tyd, wat elders omskrywe word as die "openbaring van Jesus Christus" $(1: 7,13)$, alhoewel dit nietemin verstaan word as 'n "in die Gegenwart hineinwirkende Macht" (Seethaler, 1985:21) - soos blyk uit éTó́ $\mu \eta \nu$. In hierdie verband skrywe Kendall (1986:108):

\begin{abstract}
... the expression of salvation as a climax to Christian life ... suggests that Christian life is dynamic and eschatological ... Though salvation is the goal of Christian life, it has been manifested historically in the sufferings and glories of Jesus Christ and constitutes a present reality for those who have received grace in the proclamation of the gospel.
\end{abstract}

\title{
3.2 Strofe 2 (verse 6-7)
}

Die fokus verskuif nou vanaf die toekomstige perspektief wat voortvloei uit God se daad van medelye (hoop, erfenis en verlossing), na die huidige situasie: lyding en beproewing. Alhoewel die gelowiges 'n lewende hoop op 'n heerlike erfenis ontvang omdat hulle in God glo, lewe hulle in 'n God-vyandige wêreld waarin hulle noodwendig as Christene veelvuldige beproewings sal ervaar. Ten spyte hiervan is hulle hoop lewend gerig op die blydskap wat gegrond is in hullle hoop op 'n ewige erfenis en verlossing wat vir hulle bewaar word (kyk verder Rom. 5:35; Heb. 10:32-36; Jak. 1:2; Matt. 5:11-12 en Luk. 6:22-23).

Die perspektief op hierdie beproewinge wat hulle nou nog moet deurstaan, word deur ander belangrike faktore in 'n besondere konteks geplaas wat vir gelowiges van alle tye belangrik is:

- Eerstens die feit dat dié beproewinge slegs vir 'n kort tydjie duur - in vergelyking met die ewigheidswaarde van hulle verlossing. Dit bevestig die eskatologiese ondertoon van die passasie.

- Alhoewel die frase "al is dit nodig" dui op die onvermydelikheid van lyding/beproewings (kyk Kendall, 1986:108), verwys $\delta \in \sqrt{ }$ in dié verband in besonder na die soewereine wil van God: dit berus alles in sy hande.

- Derdens het die beproewing ten doel dat die geloof daardeur getoets word. Die toetsing van hulle geloof word deur die skrywer deur middel van 'n analogie (kyk Plinius Hist. nat. 33.19.59) met die toetsing van metale omskrywe: goud is 'n kosbare metaal, maar kan deur onsuiwerhede in waarde verloor. Derhalwe het dit suiwering (deur vuur - kyk 1 Kor. 3:13) nodig om die werklike waarde daarvan na vore 
te bring. Hulle geloof is in God se oë kosbaarder as die kosbaarste metaal (goud), maar moet dieselfde pad loop as goud om tot die ware egtheid daarvan te geraak. In die vergelyking met goud moet die

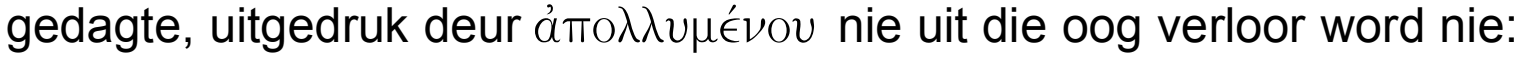
dit impliseer 'n argument vanuit die mindere na die meerdere - as goud wat vergaan, getoets moet word om tot suiwerheid te geraak, soveel te meer hulle geloof. Seethaler (1985:21) sien hierin ' $n$ verdieping van perspektief in die beeld. Die fokus val verder ook, soos Achtemeier (1996:102) aandui, meer op die aard van hierdie geloof as

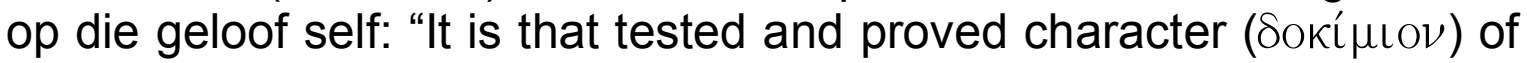

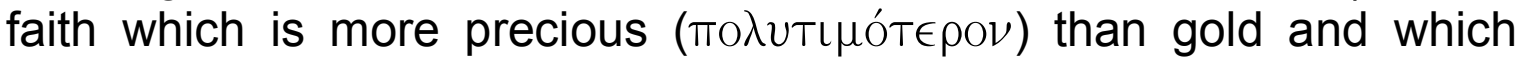
brings approval from God at the last judgement". In hierdie opsig kan

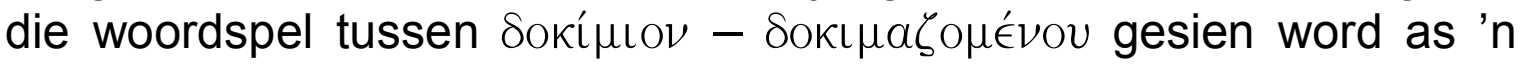
bekragtiging van die beeld van "toetsing". Die gedagte van die geloof wat getoets moet word of die toets deurstaan, kom dikwels in die Nuwe Testament voor, en veral in 'n eskatologiese konteks waarin die korte duur van die beproewings gekontrasteer word met die ewige heerlikheid wat op die gelowige wag.

- Die toetsing van hulle geloof het verder ten doel dat dit aldus - dit wil sê, wanneer dit die beproewinge deurstaan - heerlikheid en eer waardig mag wees op die dag van die Here. Aangesien die woorde

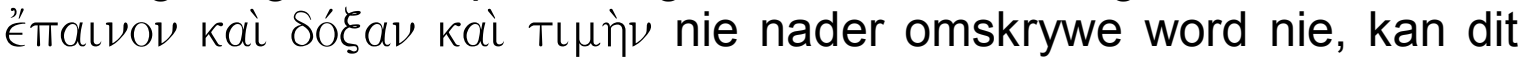
dui op sowel die erkenning van die gelowige deur God op grond van sy geloof wat die toets deurstaan het (Achtemeier,1996:102; Kendall, 1986:108) as op die feit dat God so geprys sal word. Laasgenoemde gedagte sluit aan by die openingswoorde "God moet geprys word", en kom sodoende dan ooreen met die soortgelyke frase wat die refrein vorm in die Efese-eulogie (1:6/12/14). Myns insiens pas die eerste moontlikheid die konteks die beste en word dit deur die meeste navorsers aanvaar.

\subsection{Strofe 3 (verse 8-9)}

Hierdie strofe kan gesien word as 'n gelowige en troosvolle nasê van die verrese Christus se woorde aan Tomas: "Gelukkig is dié wat nie gesien het nie en tog glo" (Joh. 20:29b). Die lesers se teenwoordige ervaring van lyding en hulle verwagte toekomstige heerlikheid en blydskap word in hierdie strofe verwoord in die vorm van 'n spanning tussen geloof en aanskoue, 'n algemene topos in die vroeë Christelike lering. Die lewe van die Christen is 'n lewe van geloof in die onsienbare Here, soos Paulus dit stel in 2 Korintiërs. 5:7: “... want ons lewe deur geloof, nie deur sien nie" (kyk ook Rom. 8:24; 10:14; Heb. 11:27). Seethaler (1985: 21-22) skrywe in dié verband: "Nicht sehen und doch glauben, nict sehen und doch lieben - in diesen Gegensatzpaaren wird das Wesen der 
christlichen Glaubenssituation offenbar". Hulle liefde en geloof sal hulle verwerkliking verkry in hulle toekomstige vreugde. Die omskrywing van hulle vreugde as "onuitspreeklik" en "heerlik", asook die perifrasme of pleonasme ("julle sal julle verbly met 'n blydskap"), dui aan die een kant op die goddelike oorsprong van hulle vreugde: dit kan nie deur menslike woorde omskryf word nie, en aan die ander kant op die eskatologiese aard daarvan: dit is met heerlikheid deurdring, 'n heerlikheid wat wag vir hulle wat getrou is aan Christus. Dit is dus 'n vreugde "lit up by the light of eternity" (Scharlemann, 1975:14). Wat hulle liefde vir Christus betref, wys Kelly (1969:57) daarop dat dit dui op die "increasing emphasis in the apostolic (or sub-apostolic) Church on personal love for Jesus". So kan Efesiërs 6:24 dan ook afsluit met die seëngroet: "Die genade sal by almal wees wat vir ons Here Jesus Christus met onverganklike liefde liefhet."

Die rede vir hulle liefde en geloof ten spyte van hulle nie-sien van Christus, word aangegee deur die teenwoordige partisipale konstruksie

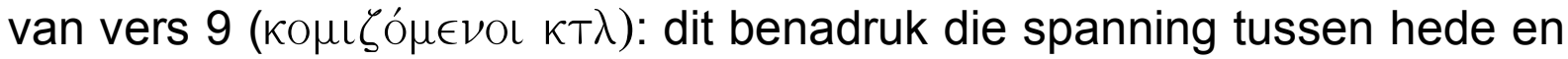
toekoms: die toekomstige verlossing van hulle siele ( $\sigma \omega T \eta \rho i ́ \alpha \psi v \cup \omega \nu)$ is reeds besig om verwerklik te word. Die frase "verlossing van julle siele" verwys hier nie na die bevryding van die "siel" uit die kerker van die liggaam nie (aangesien die woord "siel"' hier, soos oral in 1 Petrus (vgl. $1: 22 ; 2: 11,25 ; 3: 20 ; 4: 19)$ en die Nuwe Testament, in die Semitiese gebruik (vgl. Gen. 2.7) verstaan moet word: die mens as lewende wese, sy self, sy persoon), maar na die nuwe mens in God se nuwe wêreld, vrygespreek van die oordeel van God (Achtemeier, 1996:97). Dautzenberg (1964:266) wys daarop dat die uitdrukking $\sigma \omega T \eta \rho i ́ a ~ \psi v \times \omega \nu \nu$ binne 'n apokalipties-eskatologiese tradisie ontstaan het, en derhalwe slegs verstaan kan word as "Rettung der Existenz aus dem drohenden Gericht oder vor dem Gericht". Vers 9 bevestig dus vers $7 \mathrm{~b}$ : alhoewel die teenswoordige situasie van die lesers een van lyding is, sal dit nietemin uitloop op toekomstige verlossing, vreugde en heerlikheid.

\subsection{Strofe 4 (verse 10-11) en 5 (vers 12)}

Terwyl die eerste strofe heengewys het na toekomstige resultate van God se daad van die nuutmaak van gelowiges, en die tweede en derde op die huidige resultate (lyding, liefde en geloof), wys hierdie strofe terug na die verlede, waarin hierdie verlossing aangekondig is deur die profete onder die werking van die Heilige Gees (verse 11 en 12). As sodanig werp hierdie slotverse belangrike lig op die wyse waarop die vroeë Christene die Ou Testament benader en geïnterpreteer het.

Reeds die Esseners, gevolg deur sowel Christus self asook die vroeë Christene, het die Ou Testament gelees in terme van hulle eie geskiede- 
nis en heil, met ander woorde: dat die Ou-Testamentiese profesieë in hulle geskiedenis vervul is, en in besonder gefokus het op die Messias (Jesus Christus) en sy koms. So dui die verwysing na die Ou-Testamentiese profete op die kontinuïteit van God se heilsplan en derhalwe die eenheid van die goddelike openbaring, wat weer op sy beurt die sekerheid van die aangekondigde verlossing in Christus onderstreep (Achtemeier, 1996:108). Wanneer die skrywer dus hier verwys na

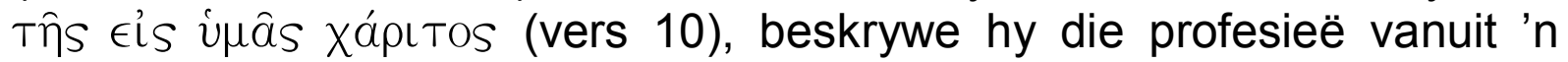
Christelike perspektief. Interessant is verder die feit dat die skrywer vermeld dat die profete met God in gesprek verkeer het oor die betekenis van hulle profesieë ten opsigte van hierdie saligheid, wat onteenseglik dui op die verlossing in Christus. Meer nog: die profete se navraag gaan spesifiek oor die tyd wanneer en die omstandighede waaronder die profesieë oor die lydinge en heerlikheid van Christus as Messias vervul sal word.

'n Verdere belangrike aspek oor hierdie Christelike lees van die Ou Testament is die feit dat die profete se werk as 'n diens aan die

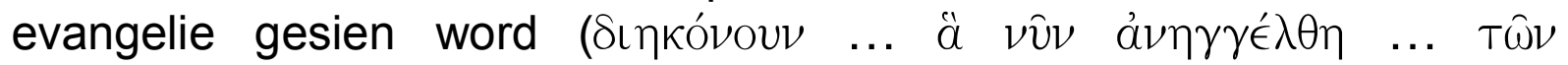
$\epsilon \dot{v} a \gamma \gamma \in \lambda\llcorner\sigma \alpha \mu \epsilon \in \nu \omega \nu$, vers 12), wat bevestig word deur die tweemalige uitwysing van die bevoordeeldes as "julle" en die gebruik van die

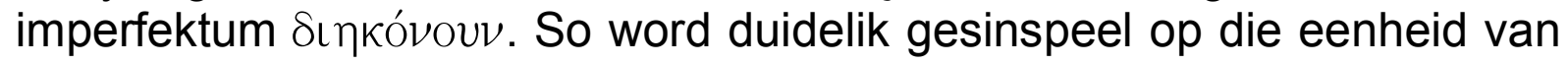
die oorsprong en inhoud van die Ou-Testamentiese getuienis en die Nuwe Testament (evangelie).

Wat die boodskap van die profete betref, word dit deur die skrywer verder deur die volgende sake belig:

- Die skrywer se skets van die profete se gretige ondersoeke van die Messiaanse tydperk weerspieël die gees van die laat-Judaïsme (Dan. 10 e.v.) en die Qumran-sektes. Hierdie strofe stam dus ongetwyfeld uit die voorstellingswêreld van die apokaliptiek. Die apokaliptici het die heil verwag as einddoel van die geskiedenis en wou die tydstip van die voleinding dus te wete kom en bereken. Die Bybelse profete word in hierdie passasie voorgestel vanuit die gesigspunt van 'n apokalipties-Christelike teologie (Seethaler, 1985:22).

- Die profesieë van die Ou Testament geld nou as die boodskap van die evangelie/kerk, soos reeds hierbo aangeraak is (kyk hiervoor 1 Kor. 15:3-5).

- Die Heilige Gees het mense in staat gestel om hierdie evangelie te verkondig (kyk Hand. 1:8; 5:32; 1 Kor. 2:14; 1 Tess. 1:5; Heb. 2:4), wat waarskynlik 'n verwysing is na die uitstorting van die Heilige Gees

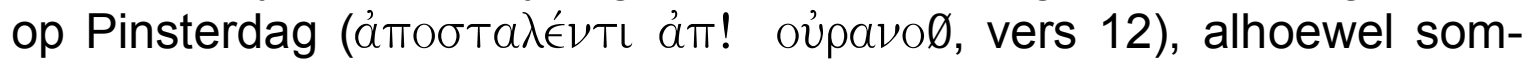
mige (bv. Achtemeier, 1996:111-112) redeneer dat dit net die 
goddelike oorsprong en inisiatief daarvan wil bevestig. Nietemin, ook hier verstaan die skrywer die kontinuïteit van die werking van die Gees (Achtemeier, 1996:113; Seethaler, 1985:22): die $\tau \mathbb{E} . . . \pi v \in \hat{v} \mu \alpha$

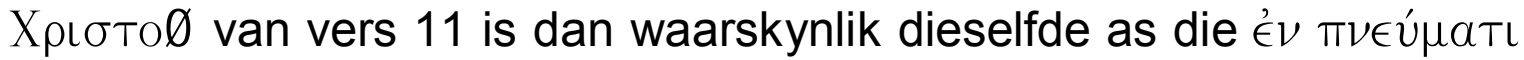
$\dot{a} \gamma i \hat{A}$ van vers 12, alhoewel sommige (Kelly, 1969:60; Achtemeier, 1996:109-110) meen dat die eerste dui op die teenwoordigheid van die pre-eksistente Christus onder die profete.

- Die byvoeging dat die engele begeer om 'n insig10 in hierdie dinge te verkry, impliseer dat hulle onbekend was met bepaalde aspekte van die mens se verlossing (kyk Mark. 13:32; Rom. 16:25; 1 Kor. 2:6-9), maar terselfdertyd wil dit ook die engele se intense interesse in God se verlossingsplan benadruk (Achtemeier, 1996:112; Seethaler, 1985: 23). Volgens Achtemeier (1996:105-107) weerspieël dit 'n apokaliptiese perspektief wat eie is aan sommige literêre genres in die Nuwe Testament. Inderdaad word dit hier nie 'n tematiese saak nie, maar beklemtoon dit nietemin die feit dat God se heilsplan voortbeweeg na die klimaks daarvan, en lê dit terselfdertyd ook nadruk op die voorreg van die gelowiges. Die voortbeweeg van God se heilsplan dien as verhoging van hulle hoop, en derhalwe as rede waarom God geprys moet word.

- Oor die spesifieke verwysing en betekenis van lydinge (vers 11) word getwyfel: omdat die normale genitiefkonstruksie ("van Christus") hier

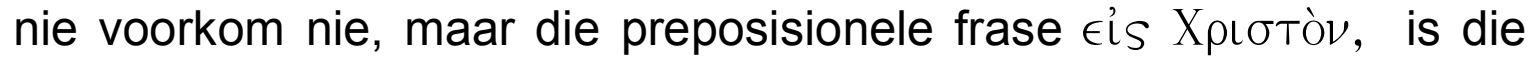
opvatting dat dit nie verwys na Christus se lydinge nie, maar na die lydinge van hulle wat Christus ten doel het. In vers 10 het ons egter 'n soortgelyke konstruksie met besitsfunksie in $\epsilon i s$ i $\mu a \hat{s}$. Die mees voor die hand liggende verklaring in hierdie konteks is dat dit heenwys na Christus se sterwe (kyk 2:21-24; 3:18; 4:1,13; 5:1), terwyl heerlikheid dui op sy opstanding, hemelvaart, sy gaan sit aan die regterhand van die Vader, en dat Hy as Regter van die lewendes en die dooies sal optree (kyk 3:22; 4:5).

\section{Samevatting: die funksie van die eulogie in 1 Petrus}

Die laaste doelstelling wat in die inleiding aangedui is, raak die funksie van die eulogie binne die breë raamwerk van die brief.

- Die skrywer dui in die inscriptio (1:1-2) met name aan wie die outeur en die addressante is, naamlik die gelowiges in die vyf Romeinse provinsies, wat oor die grootste gedeelte van Klein-Asië gestrek het.

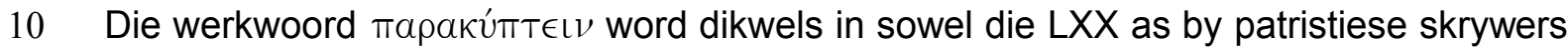
gebruik in die sin van 'n intensiewe kyk in 'n saak teenoor ander kontekste waar dit net verwys na die gedagte van "inloer", 'n "kykie kry van iets". 
Daarna roep hy in die eulogie (1:3-12) die lydende gelowiges op om God te prys vir hulle nuwe lewensbestaan deur Jesus Christus se opstanding - 'n nuwe lewensbestaan wat sal uitloop op 'n onbesmette erfenis in die hemele. Hulle huidige situasie van lyding is van korte duur, maar nietemin noodsaaklik, sodat hulle geloof getoets, en lofwaardig bevind word op die dag van die Here.

- Hierdie feit geld nou vir die skrywer as basis vir vier groepe van aansporings wat vanaf 1:13-5:11 uitdrukking vind (5:12-14 bevat die groete en slot):

- Die eerste groep aansporinge kom voor in 1:13-25: As mense wat 'n lewende hoop (1:3) besit, moet hulle hulle hoop vestig op die genade, en as gehoorsame kinders ' $n$ heilige lewe nahou. Omdat hulle geloof en hoop op God gerig is, moet hulle in eerbied vir Hom lewe gedurende hulle vreemdelingskap in die wêreld, en mekaar van harte liefhê.

- Die tweede groep vind ons terug in 2:1-10, waarin die skrywer wys op die plig van persoonlike en gesamentlike groei.

- Die derde groep kom voor in 2:11-4:19 en bevat voorskrifte vir hulle lewenswandel wat dan op verskillende verhoudings betrekking het: burgerlik (verhouding tot die landsowerheid - 2:12-17), arbeidsveld (verhouding tot werkgewers - 2:18-25), huislik (verhouding tot die huweliksmaat - 3:1-7), sosiaal (verhouding tot naaste in die algemeen -3:8-12), en hulle optrede ten opsigte van verontregting (3:13-4:19).

- Die vierde en laaste groep aansporings is kerklik van aard: hulle gedrag binne die kerklike gemeenskap (5:1-11).

Samevattend kan gestel word dat die studie aantoon dat die eulogie in 1 Petrus 1:3 e.v. die funksie van die exordium binne die geheel van die brief beklee. Die gedagtes van hoop, geloof, liefde, wat in die eulogie uitgespel word, vorm dan kennelik in die res van die brief die boustene van hulle lewe in diens van God en medemens te midde van hulle verontregtinge en diskriminasie. Die diskriminasie en verontregting wat die gelowiges in die vyf Romeinse provinsies van die kant van die Romeinse owerhede, Jode en onbekeerde huisgenote ondergaan het, is vir die skrywer die aanleiding om hulle te troos en te bemoedig: hulle is God se nuwe mense, mense wat, omdat hulle in Hom glo en Hom liefhet, deur God se mag bewaar word tydens hulle vreemdelingskap in die wêreld. Maar juis omdat hulle geroep is tot 'n nuwe lewensbestaan, en die einddoel van hulle geloof hulle verlossing is, moet hulle in al die verhoudings waarin God hulle geplaas het, heilig lewe. Hulle is nie net tot so 'n heilige lewe gewek deur Christus se opstanding uit die dood nie, maar juis ook Christus se lyding op aarde is die motivering om te midde van hulle eie lyding te volhard. 


\section{Bibliografie}

\section{Lys van afkortings:}

Ad. Eph. = Ignatius, Ad Ephesios

De bapt. = Tertullianus, De Baptismo

Hist. nat. $=$ Plinius, Historia naturalis

Inst. = Quintilianus, Institutio oratoria

Met. $=$ Apuleius, Metamorphoses

Ref. $=$ Hippolytus, Refutatio omnium haeresium

ACHTEMEIER, P.J. 1996. 1 Peter. A commentary on First Peter. Minneapolis : Fortress.

ARICHEA, D.C. \& NIDA, E.A. 1980. A translator's handbook on the First Letter from Peter. New York, London \& Stuttgart : UBS.

BARKHUIZEN, J.H. 1990. The strophic structure of the eulogy of Ephesians 1:3-14. Hervormde Teologiese Studies, 46(3):390-413.

BLASS, F., DEBRUNNER, A. \& RHEKOPF, F. 1979. Grammatik des neutestamentlichen Griechisch. Göttingen : Vandenhoeck \& Ruprecht.

CHEVALIER, M.A. 1972. 1 Pierre 1/1 à 2/10: Structure littéraire et consequences exégétiques. Revue d' Histoire et de Philosophie religieuse, 51:129-142.

COUTTS, J. 1956. Ephesians 1.3-14 and 1 Peter 1.3-12. New Testament Studies, 3:115-127.

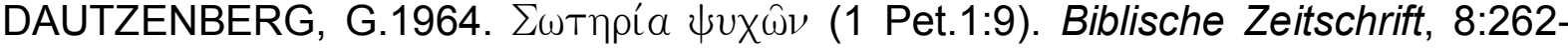
276.

DEICHGRÄBER, R. 1976. Gotteshymnus und Christushymnus in der frühen Christenheit. Göttingen : Vandenhoeck \& Ruprecht.

DU TOIT, A.B. 1974. The significance of discourse analysis for New Testament interpretation and translation: introductory remarks with special reference to 1 Peter 1.3-13. Neotestamentica, 8:54-79.

FINK, P.R. 1967. The use and significance of en ho in 1 Peter. Grace Journal, 8(2): 33-39.

GOPPELT, L. 1978. Der Erste Petrusbrief. Göttingen : Vandenhoeck \& Ruprecht.

GOPPELT, L. 1982. Theology of the New Testament. Grand Rapids : Eerdmans.

GROSHEIDE, F.W. 1954. Kol. 3:1-4; 1 Petr. 1:3-5; 1 Joh. 3:1-2. Gereformeerd Theologisch Tijdschrift, 54:139-147.

KELLY, J.N.D. 1969. The Epistles of Peter and of Jude. London : Adam \& Charles Black.

KENDALL, D.W. 1986. The literary and theological function of 1 Peter 1.3-12. (In Talbert, Ch.H., ed. Perspectives on First Peter. Macon, Georgia : Mercer University Press. p. 103-120.)

KILPATRICK, G.D. 1986. 1 Peter 1:11 TINA H IOION KAIPON. Novum Testamentum, XXVIII (1):91-92.

KROLL, J. 1968. Die Christliche Hymnodik bis zu Klemens von Alexandreia. Darmstadt : Wissenschaftliche Buchgesellschaft.

LOHSE, E. 1986. Parenesis and Kerygma in 1 Peter. (In Talbert, Ch.H., ed. Perspectives on First Peter. Macon, Georgia : Mercer University Press. p. 37-59.)

LOUW, J.P. \& NIDA, E. 1988. Greek-English Lexicon of the New Testament based on Semantic Domains. Vol. 1 en 2. New York : United Bible Societies.

MARSHALL, I.H. 1991. 1 Peter. Illinois : Downers Grove. (The IVP New Testament Commentary Series, Intervarsity Press.) 
MARTIN, T. 1992. The present indicative in the eschatological statements of 1 Peter 1:6, 8. Journal of Biblical Literature, 111:307-312.

NEUGEBAUER, F. 1980. Zur Deutung und Bedeutung des 1. Petrusbriefes. New Testament Studies, 26:61-86.

RICHARD, E. 1986. The functional Christology of First Peter. (In Talbert, CH.H., ed. Perspectives on First Peter. Macon, Georgia : Mercer University Press. p. 121139.)

SANDERS, J.T. 1962. The transition from opening epistolary Thanksgiving to Body in the Letters of the Pauline corpus. Journal of Biblical Literature, 81:348-362.

SCHARLEMANN, M.H. 1975. An apostolic descant (An exegetical study of 1 Peter 1.3-12). Concordia Journal, 2:9-17.

SCHUTTER, W.L. 1989. Hermeneutic and composition in 1 Peter. Tübingen : Mohr. (Wissenschaftliche Untersuchungen zum Neuen Testament 2/30.)

SEETHALER, P-A. 1985. 1. und 2. Petrusbrief/Judasbrief. Stuttgart : Verlag Katholisches Bibelwerk. (Stuttgarter Kleiner Kommentar, Neues Testament 16.)

SMYTH, H.W. 1959. Greek Grammar. Cambridge : Harvard University Press.

THÚREN, L. 1995. Argument and theology in 1 Peter. Sheffield : Sheffield Academic Press. (Journal for the Study of the New Testament. Supplement Series 114.)

WHITE, J.L. 1972. The form and function of the body of the Greek letter: A study of the letter-body in the non-literary papyri and in Paul the Apostle. Montana : Missoula.

WHITE, J.L. 1984. New Testament Epistolary Literature in the framework of ancient epistolography. Aufstieg und Niedergang der Römischen Welt, II.25.2:17301756.

WINDISCH, H. 1951. Die Katholilschen Briefe. Tübingen : Mohr.

\section{Kernbegrippe:}

eulogie as exordium

funksie van eulogie

strofiese opbou

teologiese perspektief

\section{Key concepts:}

eulogy as exordium

function of eulogy

strophic structure

theological perspective 